\title{
Latest updates on chronic viral hepatitis B
}

\author{
Kronik viral hepatit B tedavisinde yenilikler
}

Ramazan IDILMAN, Fatih KARAKAYA

\begin{abstract}
Hepatitis B virus (HBV) remains a major cause of liver-related morbidity and mortality in Turkey and all over the world. Two different types of antiviral agents can be used in the treatment of chronic hepatitis B (CHB). Conventional (IFN) or pegylated interferon alpha (PegIFN), nucleoside [lamivudine (LMV), telbivudine, emtricitabine, entecavir (ETV)] and nucleotide analogs [adefovir dipivoxil (ADV)] and tenofovir disoproxil fumarate (TDF)]. Antiviral agent must ensure a degree of HBV viral suppression and will lead to biochemical, serological remission and histological improvement. Current treatment strategies are discussed in present brief report.
\end{abstract}

Keywords: Chronic hepatitis B, Nucleos(t)ide analog, Entecavir, Tenofovir disoproxil fumarate

\section{Öz}

Hepatit B Türkiye'de ve dünyada major bir sağlık problem olup karaciğer hastalıklarına bağlı morbidite ve mortalitede önemli bir yer tutmaktadır. İnterferonlar ve oral anti-viral ajanlar olan nukleotid ve nükleozid analogları tedavide uygulanmaktadır. Bu derlemede tedavi rejimleri, uygulamaları ve sonuçları ayrıntılı olarak belirtilmiştir.

Anahtar kelimeler: Kronik hepatit B, Nükleoz(t)id analog, Entekavir, Tenofovir disoproksil fumarat

Ramazan Idilman (西), Fatih Karakaya

Sub-department of Gastroenterology, School of Medicine, Ankara

University, Cebeci, Ankara-Turkey 06100

e-mail:idilman@medicine.ankara.edu.tr

Fax: +903123636213

\section{Introduction}

Hepatitis B virus (HBV) remains a major cause of liverrelated morbidity and mortality in Turkey. Morbidity and mortality are linked to persistence of viral replication and evolution to end-stage liver disease. Viral suppression with antiviral therapy has achieved clinical benefits as a result of prevention of disease progression, reduction in hepatic decompensation in chronic hepatitis $\mathrm{B}$ (CHB) patients. There have been great evolutions in the management of CHB infection. The aim of this present review was to focus on latest updates on the management of $\mathrm{CHB}$ infection.

\section{Epidemiology}

An estimated 350 million individuals are chronically infected with HBV in worldwide [1]. In Turkey, Hepatitis B surface antigen (HBsAg) positivity was $4 \%$ based on the result of an epidemiological study [2]. HBV infection is present in approximately $50 \%$ of the patients with hepatocellular cancer (HCC), most of whom have cirrhosis. In 2013, HBVrelated end-stage liver disease with/without HCC accounted for approximately $40-50 \%$ of cases of liver transplantation in Turkey. The spectrum of HBV-related disease is variable, ranging from an inactive $\mathrm{HBV}$ carrier state to progressive CHB, which may evolve to cirrhosis and its complications such as portal hypertension or HCC. Every year, around 1 million individuals die as a result of HBV-related end stage liver disease and its complications [3].

\section{The Natural Course of the Disease}

$\mathrm{CHB}$ infection is a dynamic process. The natural course of the HBV-related disease consists of 5 phases [4]. A careful assessment of the CHB patients is necessary. 


\section{Immune tolerant phase}

The immune tolerant phase represents a high rate of HBV replication and low rate of hepatic inflammation. This phase is characterized by $\mathrm{HBeAg}$ positivity, high serum $\mathrm{HBV}$ DNA levels, persistently normal serum ALT levels, minimal histological liver damage. This patient represents a significant source of horizontal and vertical transmission. $\mathrm{HBeAg}$-positive patients with immuntolerant phase should be monitored regularly and that antiviral therapy should be started when the patients show signs of active liver disease including serum ALT level higher than twice the upper limit of normal and/ or at least moderate histological liver damage (Histological activity index $[\mathrm{HAI}] \geq 6$ and/or fibrosis score $\geq 2$ ).

Immun reactive $\mathrm{HBeAg-positive} \mathrm{phase}$

This phase is characterized by $\mathrm{HBeAg}$ positivity with lower level of HBV replication. During this period, a high or fluctuating levels of serum ALT and HBV DNA levels is seen and moderate and severe necroinflammation is observed. This state may occur after several years of immune tolerance, and may last for several weeks to years, and ends with seroconversion to antiHBe.

\section{Inactive HBV carrier state}

This phase may follow seroconversion to antiHBe antibody. Serum HBV DNA level is either very low $(2.000 \mathrm{IU} / \mathrm{ml})$ or is undetectable with normal serum ALT level. At least minimum 1-year follow up (serum ALT and HBV DNA levels) is necessary before classifying a patient as inactive $\mathrm{HBV}$ carrier. Some inactive carriers may have serum HBV DNA levels greater than $2.000 \mathrm{IU} / \mathrm{ml}$ (usually $<20.000 \mathrm{IU} /$ $\mathrm{ml}$ ) with persistently normal ALT levels. This state may progress to CHB. Moreover, inactive carrier patients should follow for very low risk development of cirrhosis or HCC. AntiHBs antibody may also develop spontaneously in 1-3\% of patients per year.

\section{HBeAg negative CHB state}

This state may develop seroconversion of $\mathrm{HBeAg}$ to antiHBe or may develop after years of the inactive HBV carrier state. It is characterized by a pattern of fluctuating levels of serum ALT and HBV DNA with active hepatitis. This state have active disease with a high risk of progression to advance liver disease.

\section{HBsAg negative state}

Low-level HBV replication may persist with detectable serum HBV DNA in the liver after HBsAg loss. HBV DNA generally is not detectable in the serum, but antiHBc and hepatitis B surface antibody (antiHBs) antibodies are positive.

\section{Treatment}

The assessment of the severity of the HBV-related liver disease should be performed before start antiviral therapy. CHB patients should be evaluated in detail about their previous health history and physical examination. Alcohol usage, family history of $\mathrm{HBV}$ and $\mathrm{HCC}$ should be all investigated. Biochemical markers including serum ALT, aspartate transaminase (AST), gamma-glutamyl transpeptidase, alkaline phosphatase, bilirubin, albumin, prothrombin time, blood counts, serological (serum HBV markers, HBV DNA detection) and histological evaluation should be performed. Serum HBV DNA levels should be expressed in IU/ml to ensure comparability. Other causes of chronic liver disease including coinfection with hepatitis $\mathrm{C}$ virus, hepatitis Delta virus and human immunodeficiency virus infections) should be rule out. Abdominal sonography should be performed. A liver biopsy should be performed to demonstrate degree of necroinflammation and fibrosis [5]. A liver biopsy is generally not required in patients with clinical evidence of cirrhosis.

The purpose of the treatment is to prevent HBVrelated disease progression, cirrhosis, decompensation, HCC development; and therefore to increase the survival. Virological response is associated with a better clinical outcome in CHB patients [6-11]. Moreover, HBV viral suppression with antiviral therapy was able to reduce to incidence of disease progression and improved the clinical outcome.

Two different types of antiviral agents can be used in the treatment of CHB. Conventional (IFN) or pegylated interferon alpha (PegIFN), nucleoside (lamivudine [LMV], telbivudine, emtricitabine, entecavir [ETV]) and nucleotide analogs (adefovir dipivoxil [ADV] and tenofovir disoproxil fumarate $[\mathrm{TDF}]$ ) (Table 1). Antiviral agent must ensure a degree of HBV viral suppression and will lead to biochemical, serological remission and histological improvement.

The indication to the initiation of antiviral treatment for both $\mathrm{HBeAg}$-positive and $\mathrm{HBeAg}$-negative patients is as follows [4];

- Serum ALT level (normal or above the upper limit of normal)

- $\quad$ Serum HBV DNA level ( > $20000 \mathrm{IU} / \mathrm{mL}$ )

- The severity of the liver disease (moderate and severe necroinflammation ( $[\mathrm{HAI} \geq 6]$ and/or at least moderate fibrosis [fibrosis score $\geq 2]$ ).

Patient age, health status, family history of HCC or cirrhosis and extrahepatic manifestations should be considered before treatment initiation. 
Table I. Antiviral therapies in treatment of CHB [6]

\begin{tabular}{|c|c|c|c|c|}
\hline Drug & Dose & $\begin{array}{l}\text { Pregnancy } \\
\text { Category }\end{array}$ & Potential Side Effects & Monitoring on Treatment \\
\hline Peg-IFN-2a & $180 \mu \mathrm{g}$ weekly & $\mathrm{C}$ & $\begin{array}{l}\text { Flu-like symptoms, fatigue, } \\
\text { mood disturbances, cytopenias, } \\
\text { autoimmune disorders }\end{array}$ & $\begin{array}{l}\text { CBC (monthly to every } 3 \text { months) } \\
\text { Clinical monitoring for autoimmune, } \\
\text { ischemic, neuropsychiatric, and } \\
\text { infectious complications }\end{array}$ \\
\hline Lamivudine & $100 \mathrm{mg} /$ day & $\mathrm{C}$ & $\begin{array}{l}\text { Pancreatitis } \\
\text { Lactic acidosis }\end{array}$ & $\begin{array}{l}\text { Amylase if symtoms exist } \\
\text { Lactic acid levels if clinical concern }\end{array}$ \\
\hline Telbivudine & $600 \mathrm{mg} /$ day & $\mathrm{B}$ & $\begin{array}{l}\text { Creatine kinase elevations and } \\
\text { myopathy } \\
\text { Peripheral neuropathy }\end{array}$ & Creatinine kinase if symptoms exist \\
\hline Entecavir & 0,5 or $1 \mathrm{mg} /$ day & $\mathrm{C}$ & Lactic acidosis & Lactic acid levels if clinical concern \\
\hline Adefovir Dipivoxil & $10 \mathrm{mg} /$ day & $\mathrm{C}$ & $\begin{array}{l}\text { Acute renal failure } \\
\text { Fanconi syndrome } \\
\text { Nephrogenic diabetes insipidus }\end{array}$ & $\begin{array}{l}\text { Creatinine clearance at baseline } \\
\text { If at risk for renal impairment, creatinine } \\
\text { clearance, serum phosphate, } \\
\text { urine glucose, and protein at least } \\
\text { annually }\end{array}$ \\
\hline $\begin{array}{l}\text { Tenofovir disoproxil } \\
\text { fumarate }\end{array}$ & $300 \mathrm{mg} /$ day & B & $\begin{array}{l}\text { Nephropathy, Fanconi syndrome } \\
\text { Osteomalacia }\end{array}$ & $\begin{array}{l}\text { Creatinine clearance at baseline } \\
\text { If at risk for renal impairment, creatinine } \\
\text { clearance, serum phosphate, } \\
\text { urine glucose, and protein at least } \\
\text { annually } \\
\text { Consider bone density study at baseline } \\
\text { and during treatment in persons } \\
\text { with history of fracture or risks } \\
\text { for osteopenia }\end{array}$ \\
\hline
\end{tabular}

Treatment responses can be divided into biochemical, serological, virological and histological. Biochemical response is defined as normalization of the serum ALT levels. Serological response is defined by the loss of $\mathrm{HBeAg}$ and the seroconversion to antiHBe in patients with $\mathrm{HBeAg}$ positivity; and the loss of HBsAg and development of antiHBs. Virological response is defined as a serum HBV DNA level of less than $2.000 \mathrm{IU} / \mathrm{ml}$ after the end of therapy for IFN or PegIFN therapy, and sustained at least 12 months after the end of therapy. In fact, virological response for NA therapy is defined as undetectable a serum HBV DNA level [4]. Histological response is defined as decrease in necroinflammatory activity as a $\geq 2$ points in HAI without worsening fibrosis score as compare to baseline histology.

The ultimate goal of effective antiviral therapy is HBsAg loss and seroconversion to antiHBs. HBsAg seroclearance predicts long-lasting viral suppression, diminished disease progression and improved clinical prognosis as well as decreased risk of cirrhosis and HCC. HBsAg seroclearance can be achieved after IFN-based anti-viral therapy, whereas it is suboptimal under oral antivirals $[6,10]$.

The efficacy of antiviral drugs for CHB has been assessed in randomized controlled trials in short-term and longterm (Table I). Basically, there are two different treatment strategies, PegIFN or IFN treatment with finite duration or a long-term NA treatment, for both HBeAg-positive and negative patients.

PegIFN treatment is more commonly preferred because its more favorable safety and tolerability profile as compare to IFN treatment. Approximately $30 \%$ of HBeAg-positive patients respond to a 48 -week course of PegIFN therapy. Young age, HBV genotype (genotype $\mathrm{A}>\mathrm{B}>\mathrm{C}>\mathrm{D}$ ), low serum HBV DNA and ALT levels are important baseline predictive factors for better respond to therapy. Immune modulator and no resistance profile effect are advantages of PegIFN therapy, while the frequent side effects and subcutaneous injection are main disadvantages. Therapy respond is low in $\mathrm{HBeAg-negative} \mathrm{patient,} \mathrm{especially}$ in patients with genotype D. PegIFN treatment is contraindicated in cirrhotic patients with Child-Pugh B and 
$\mathrm{C}$, in patients with autoimmune disease, in patients with severe psychiatric problems and in pregnant women [6].

ETV and TDF, third generation NAs, are currently recommended as monotherapy. ETV and TDF are potent inhibitors of HBV polymerase/reverse transcriptase with minimal or no drug resistance $[12,13]$. These two agents led to an undetectable serum HBV DNA in the vast majority of patients with CHB (>90\%) within months or a few years of therapy. These two agents are more rapidly achieved in $\mathrm{HBe} A g-$ negative patients than in $\mathrm{HBe} A g$-positive patients. Real-life data confirm that on-treatment inhibition of HBV replication can be achieved in almost $100 \%$ of compliant CHB patients treated with ETV or TDF. Serological responses increase over time with approximately $40 \%$ $\mathrm{HBeAg}$ conversion. However, HBsAg loss is achieved around $1 \%$ of $\mathrm{HBeAg}$-negative patients at year 5 of followup. Histologically, necroinflammation improves and fibrosis regresses in most patients with CHB. The reversal of cirrhosis is possible if there is a thinning of the fibrous septa present. However, cirrhosis is a complex disease with a wide spectrum and reversal of disease will not be possible in all cases.

Treatment failure can be defined as primary nonresponse, partial virological response and virological failure. Primary non-response on NA is defined as less than $1 \log _{10}$ $\mathrm{IU} / \mathrm{ml}$ decrease in serum HBV DNA level at 3 months of therapy as compare to baseline. Primary non-response to NA is rarely seen. Partial virological response is defined as a decrease in serum HBV DNA levels of more than $1 \log _{10}$ $\mathrm{IU} / \mathrm{ml}$, but detectable after 6 months or 1 year of therapy if patient is compliant to drug. Virological breakthrough is defined as a detected increase in serum HBV DNA level of more than $1 \log _{10} \mathrm{IU} / \mathrm{ml}$ compare to undetectable HBV DNA level on antiviral therapy. It is important to distinguish these three terminologies.

It is always important to check for patient's compliance during treatment failure. When LMV or telbivudine fail, it is preferable a switch to a more potent agent such as TDF or ETV. When ETV or TDF fail, it is debatable; a switch is preferable strategy in most cases or may require an addon strategy in difficult cases at week 48. If patients have declining serum HBV DNA levels at week 48, it may continue treatment with the same agent.

In case of LMV resistance, a switch to TDF is as effective strategy. In case of resistance to telbivudine, a switch to TDF is the preferred strategy. In case of ADV resistance, a switch to or adding on TDF is the effective strategy. It is note that early intervention is important to prevent accumulation of mutations and disease progression.

Long-term HBV suppression prevents disease progression to cirrhosis and decompensation. Portal hypertension is also improved in compensated cirrhotic patients. It is note that the mechanism of hepatocarcinogenesis is complex. The annual risk of HCC in CHB patients and compensated cirrhotic patients was $0.8 \%$ and $2.5 \%$. The impact of longterm ETV or TDF treatment on HCC risk remains unclear. Asian studies reported that risk of $\mathrm{HCC}$ reduced under long-term NAs treatment, however it did not confirm by European studies in CHB patients with/without cirrhosis. It may conclude that $\mathrm{HCC}$ rates tend to decrease in $\mathrm{CHB}$ patients, who successfully treated for more than 5 years with potent NAs such ETV or TDF [14].

All NAs are well tolerated with low rates of discontinuation. Both ETV and TDF are associated with good safety profiles. Renal function should be monitorized, especially in patients with decompensation and in patients with co-morbidities [13].

The best and safest stopping rule for CHB patients under long-term NA treatment is HBsAg loss and antiHBs seroconversion (titer more than $100 \mathrm{IU} / \mathrm{ml}$ ) [15]. However, antiHBs seroconversion is rarely seen under long-term NA treatment. International guidelines do not recommend any discontinuation strategy. Even that, discontinuation of NA treatment depends on the individual patient and the experience of the clinician. Discontinuation should never be attempted in decompensated cirrhotic patients.

\section{Key Points}

- Hepatitis B virus remains a major cause of liverrelated morbidity and mortality in Turkey.

- ETV and TDF effectively maintained virological and biochemical responses in CHB patients with/without cirrhosis.

- Long-term effective NAs treatment extends patient survival as a result of reduction of liver disease complications in cirrhotic HBV-patients.

- HCC may still develop under NAs treatment, though at a lower rate in CHB patients with cirrhosis.

\section{Conflict of Interest}

The authors declare no conflicts of interest; no financial support was received for the conduct of this study. 


\section{References}

1. Ott JJ, Stevens GA, Groeger J, Wiersma ST. Global epidemiology of hepatitis B virus infection: new estimates of age-specific HBsAg seroprevalence and endemicity. Vaccine 2012;30:2212-19, doi: 10.1016.

2. Tozun N, Ozdogan OC, Cakaloğlu Y, et al. Seroprevalence of hepatitis $\mathrm{B}$ and $\mathrm{C}$ virus infections and risk factors in Turkey: a fieldwork TURHEP study, Clin Microbiol Infect. 2015 Nov;21:1020-6. doi: 10.1016/j.cmi.2015.06.028.

3. Lok AS, McMahon BJ. Chronic hepatitis B. Hepatology 2007;45:507-39.

4. EASL Clinical Practice Guidelines: Management of chronic hepatitis B virus infection. J Hepatol 2012;57: 167-85. doi: 10.1016/j.jhep.2012.02.010.

5. Lok A, McMahon B, Brown R, et al. Antiviral therapy for chronic hepatitis B virus infection in adults: a systematic review and meta-analysis. Hepatology 2015;63:284-306. doi: 10.1002/hep. 28280

6. Terrault NA, Bzowej NN, Kyong MS, Hwang JP, Jonas PP, Murad MH. AASLD Guidelines for Treatment of Chronic Hepatitis B. Hepatology 2016;6:261-83. doi: 10.1002/ hep. 28156

7. Chaung KT, Ha NB, Trinh HN, et al. High frequency of recurrent viremia after hepatitis $\mathrm{B}$ e antigen seroconversion and consolidation therapy. J Clin Gastroenterol 2012;46:86570. doi: 10.1097/MCG.0b013e31825ceed9

8. Hadziyannis SJ, Sevastianos V, Rapti I, Vassilopoulos D, Hadziyannis E. Sustained responses and loss of HBsAg in HBeAg-negative patients with chronic hepatitis B who stop long-term treatment with adefovir. Gastroenterology 2012;143:629-36.e, doi: 10.1053/j.gastro.2012.05.039.

9. Buster EH, Hansen BE, Buti M, Delwaide J, Niederau C, Michielsen PP, et al. Peginterferon alpha- $2 b$ is safe and effective in $\mathrm{HBeAg}$-positive chronic hepatitis B patients with advanced fibrosis. Hepatology 2007;46:388-94.

10. Schiff E, Simsek H, Lee WM, et al. Efficacy and safety of entecavir in patients with chronic hepatitis B and advanced hepatic fibrosis or cirrhosis. Am J Gastroenterol 2008;103:2776-83. doi: 10.1111/j.1572-0241.2008.02086.

11. Buti M, Hadziyannis S, Mathurin P, et al. Tenofovir disoproxil fumarate is highly active for treatment of chronic hepatitis B in subjects with cirrhosis. J Hepatol 2008;48:S33.

12. Chang TT, Liaw YF, Wu SS, et al. Long-term entecavir therapy results in the reversal of fibrosis/cirrhosis and continued histological improvement in patients with chronic hepatitis B. Hepatology 2010;52:886-93. doi: 10.1002/ hep. 23785 .

13. Idilman R, Gunsar F, Koruk M, et al. Long-term entecavir or tenefovir disoproxil fumarate therapy in treatment-naive chronic hepatitis B patients in the real-world setting. J Viral Hepatit 2015;22:504-10 doi:10.1111/jvh.12358.

14. Papatheodoridis GV, Lampertico P, Manolakopoulos S, Lok A. Incidence of hepatocellular carcinoma in chronic hepatitis $\mathrm{B}$ patients receiving nucleos(t)ide therapy: a systematic review. J Hepatol 2010;53:348-56, doi: 10.1016/j. jhep.2010.02.035.

15. Cornberg M, Protzer U, Petersen J, et al. Prophylaxis, diagnosis and therapy of hepatitis $\mathrm{B}$ virus infection - the German guideline. Z Gastroenterol 2011;49:871-930. doi: 10.1055/s-0031-1273462. 